\title{
MAQASID IN RISK MANAGEMENT: AN ANALYSIS OF IJARAH CONTRACT WITH SPECIAL REFERENCE TO MALAYSIA
}

\author{
Ahmad Badri Abdullah and Tawfique Al-Mubarak*
}

\begin{abstract}
Ijārah-based financing is currently generating greater interest among industry players and policy makers due to its minimal risk exposure. Being assetbacked it has a lesser risk overload, no default risk and better profits and now offers a viable alternative to controversial debt-based financing instruments. This paper attempts to highlight the benefits of applying the objectives (maqāsid) of ijärah contract and how a diligent compliance to its maqasid can help manage Shari'ah and business risks. It is also hypothesised in this study that a sincere compliance tov the Shari'ah's objectives in financial transaction (maqāsisid al-mu'āmalāt) would reduce risks in the Islamic banking industry. Current applications of ijärah-based instruments by Islamic banks in Malaysia are analysed to show the gaps between its theoretical presumptions and the actual applications on the ground. Some unresolved Shari'ah issues relating to the implementation of al-ijärah thumma al-bay (AITAB) (a contract of leasing ending with a sale) as well as issues regarding șukūk al-ijärah (leasing bond) are discussed in order to provide evidence for such dissonances. The study recommends constructive measures to be undertaken by policy makers to resolve the governance and legal problems with regard to the implementation of AITAB and șukūk al- ijārah.
\end{abstract}

Keywords: Ijārah, maqāṣid al-mu'āmalāt, al-ijārah thumma al- bayc (AlTAB), șukūk al-ijārah, hire purchase

\section{Introduction}

Ijārah closely resembles 'leasing' or 'hire purchase' in the conventional banking system. Contemporary scholars find it a valuable tool to earn legitimate profit while avoiding usury $(r i b \bar{a})$ in Shari'ah compliant financial transactions. It is an asset-backed mode of financing, which has a lesser risk overload, no default risk, and better prospects of profit for the Islamic banks and its clients.

Although primarily the objectives (maqāșid) have been broadly categorised into three categories of necessity ( $\operatorname{dar} \bar{u} r \bar{\imath})$, needs (hājī) and luxury (tạ̣sīnī), further classifications include the general objectives (maqașid'ammah), the specific objectives (maquassid khāsșah), and the partial objectives (maqāṣid juz'iyyah). Generally, the objectives of financial transactions (maqāssid almu 'amalat ) would fall under the category of specific objectives, since these only deal with certain objectives of a specific branch of knowledge of the Shari'ah. Ibn 'Âshūr identified five maqāṣid for the financial transactions, namely: 


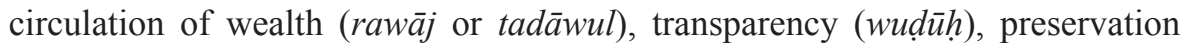
(hifz), constancy (thubutt), and equity ('adl). Similarly, other objectives such as development of human civilisation (isti $m \bar{a} r$ al-ard ), social and economic growth, poverty alleviation and opening up employment opportunities, could be considered among the Shari'ah objectives regarding financial transactions in the context of evolving circumstances. Considering the above mentioned objectives from the broad range of the five essential objectives identified by al-Ghazālī, these would serve the purpose of preservation of wealth ( hifz al-māl) altogether.

This paper attempts to identify the Shari'ah objectives upheld by the ijārah contract specifically and consequently how such compliance helps in managing Shari'ah and business risks. The paper hypothesises that a sincere compliance to the objectives of financial transactions would reduce risks in Islamic banking industry. Moreover, it also analyses the current practice of ijārah-based instruments in Islamic banks so as to highlight the dissonance between theoretical presumptions and the actual applications on the ground.

\section{The Ijärah Contract: Definition and Scope}

Ijärah is an Arabic word, derived from al-ajr which means substitute, compensation, recompense, reward, return or counter value ('iwaḍ). ${ }^{1} \mathrm{Al}-\mathrm{Ka} s a \bar{n} \overline{1}$ notes that the Qur'ānic term ujār (sl. ajr) denotes anything that is given in exchange for a usufruct. ${ }^{2}$ The terms kirā', iktirā' and isti 'jār are also synonymously used for ijärah in the classical fiqh books. The Mālikī scholars generally use the term ijärah for contracts of services, like the services of a porter, a shepherd, or a teacher; while the term kira $\bar{a}$ ' is often used for renting and leasing assets or properties. $^{3}$

Ijārah is a contract of sale of specified usufruct for a counter value. The usufruct and the time period it is valid for should be specifically defined in the contract. $^{4}$

Ijārah is established from the Qur'ānic narrative of Prophet Shu'aib and his two daughters (28:26-27), in which the prophet was advised by one of his daughters to hire prophet Mūsā on wages. In another verse, prophet Mūsā told Khidir that he could have demanded recompense for setting up the wall straight (18:77). These verses imply that ijärah was already in practice during the time of prophets Shu aib and Mūsā. Similarly, the verses on hiring wet nurses on wages for their services $(2: 233$, and $65: 6-7)$ further substantiate the legality of ijärah.

The report (hadith) narrated by ' $\overline{\mathrm{A}}$ ' isha, may Allah be pleased with her, about the Prophet, pbuh, and Abu Bakr engaging an expert guide to usher them to Madinnah during their migration, is an authentic (sahịh) report which proves the practice of ijarrah by the Prophet himself. ${ }^{5}$ The Prophet also commanded the 
believers to pay the wages of the employee (ajār) before his sweat dries up, with no delay. ${ }^{6}$ This is in fact a confirmation of permission for the ijärah contract.

The pillars of an ijärah contract, according to the Hanafi School are the offer and the acceptance, but other schools also include the two parties of the ijärah contract and the subject of the contract (i.e. the usufruct and the rental agreed upon) among the pillars. ${ }^{7}$ However, the Hanafi scholars consider the other two components among the inevitable conditions for an ijärah contract. ${ }^{8}$

An ijärah contract ideally needs to fulfill some basic conditions, which includes:

1. The subject of ijärah should be existent, and have a valuable use. Things with no usufruct at all cannot be leased.

2. The corpus of the asset should remain under the ownership of the lessor, and only the usufruct is transferred to the lessee. Therefore, any item which cannot be used unless it is consumed cannot be considered for lease, for example food, money, fuel, etc. These falls under the rules of loan, and not lease, hence any rental imposed on these items will be considered as usury. ${ }^{9}$ The Hanafī scholar al-Kāsānī presents examples of leasing a dirham or some wheat leased for weighing, whereas the corpus remains unconsumed, hence the charge of rental on the lease will be valid. ${ }^{10}$

3. It is also important that both the parties in ijärah should have consent on the contract. ${ }^{11}$

4. The usufruct of the asset should be defined and specified.

5. The rental and the period of the lease should be clearly determined.

6. The lessor should be fully capable of handing over the asset to the lessee for its uses. ${ }^{12}$ And also that the leasing period should not go beyond the useful life of the asset. In both the cases, the usufruct will not be accessible; hence the contract will be rendered invalid.

7. Since the ownership of the leased asset remains with the lessor, he has to pay for all relevant liabilities emerging from the ownership, like tax, and maintenance cost, etc. And the lessee will only be liable to pay for costs emerging from the use of the asset, like electricity and water bills in a house lease, and road tax in the case of a car lease, etc.

8. The lessee is liable to compensate the lessor for any damage caused to the asset due to negligence or misuse from the part of the lessee. And if the damage was caused due to factors beyond the control of the lessee, the lessor shall bear the cost as the owner of the asset. ${ }^{13}$ 


\section{Maqāṣid al-Sharī̄ah and the Maqāṣid al-Mu'āmalāt}

The term maqsad refers to "purpose, objective, principle, intent, goal, end..."14 And it denotes the purposes behind the rulings in the Shari'ah, in the simplest sense. It had also been used interchangeably with the term mașlahah (interest/ benefit) or similar words in the works of the earliest contributors in the field of maqāṣid, like those of Imām al-Haramayn al-Juwainī (d.478 H.), Abū Hāmid alGhazālī (d.505 H.), Fakhr al-Dīn al-Rāzī (d.606 H), Saif al-Dīn al-Āmidī (d.631 H.), Najm al-Dīn al-Ṭūfì (d.716 H) and others. In fact, al-Ṭūfì went on further to declare that no purpose or objective (maqșad) is valid as long as it does not bring in a benefit (mașlahah) or repels harm (mafsadah). ${ }^{15}$ The deep-rooted relationship between the two terms is quite evident from this. However, there are also some differences between the two terminologies. The benefits (mașālīh) are described

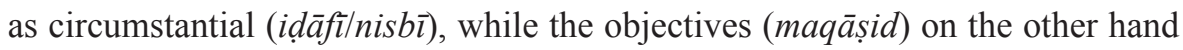
are meant to be constant and permanent, hence stand a degree above the ranks of the benefits. Likewise, the objectives are based on the textual grounding in the Qur'ān and the Sunnah, while only the accredited benefits(mașālīh mu 'tabarah) has a similar grounding unlike the unrestricted benefits (mașālīh mursalah) or the nullified benefits (mașālīh mulgha). ${ }^{16}$

Al-Ghazālī categorised the objectives into two primary categories; the religious $(\operatorname{din} \bar{\imath})$ objectives and the temporal (dunyaw $\bar{\imath})$ objectives. The temporal purposes are further divided into four types, which are all individually meant to serve the single religious purpose. The four temporal purposes are the protection of life ( $n a f s$ ), intellect, progeny, and property ( 'aql, nasl and $m \bar{a} l$ respectively). ${ }^{17}$ Al-Shătibī further categorised the Shari'ah ordinances into three levels; i) the

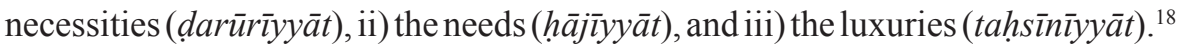
The first level of objectives, the level of necessities, represents essential matters without which the life would be chaotic and disastrous. These necessities are the five essentials which al-Ghazālī considered in his categorisation; i.e. preservation of one's faith, life, lineage, wealth and intellect. Al-Qarāfī added a sixth essential, the preservation of dignity and honor ( $\mathrm{ird}$ ). The second level of objectives, the needs level ( $h \bar{a} \bar{j} \bar{y} y y \bar{a} t)$, are those which are required to repel hardship in one's living. For instance, marriage, education, trading, etcetera is not obligatory upon individuals. Individuals may opt to marry or not to marry, to educate themselves or not to educate, and as such is not a threat to their life. However, without these one has to face hardship. On a similar note, if these become widespread it may become a threat to the society as a whole hence would render a matter of necessities (darūrīyyāt). And the third level is that of the luxuries (tahsinnīyyāt), or the level of luxuries and beautifications, which makes one's life easier to easiest. Typical examples of this category include one's choice to use perfume, 
or beautiful clothing, comfortable cars, or spacious homes and others alike. Although these are encouraged in Islam as indications of Allah's mercy upon His servants, they should not be among the priorities of an individual.

These levels of objectives proposed by the classical Islamic jurists have faced the need for revision in compliance with the contemporary needs of the society. The objectives, as they have proposed, have been classified into three hierarchical levels: 1) the general objectives ('ammah), 2) the specific objectives (khāsșah), and 3) the partial objectives (juz'iyyah). ${ }^{19}$ The first level of the objectives is deemed observable at the highest level of Shari'ah like the preservation of the five necessities, establishment of justice, facilitation, confirming human rights and dignity etc. The specific objectives are often observed at a specific scope within the Shari'ah, like the objectives in the laws of inheritance, objectives of the financial transactions, objectives of the criminal law, or objectives of worship matters ( $i b \bar{a} \bar{a} \bar{t}$ ) etc. And the third level is the objectives behind a specific ruling or a specific issue. For instance, the objectives behind dower (mahr) in marriage, objective behind having witnesses in contracts, objectives behind the prohibition of usury, objectives behind the commandment of almsgivings (zakāh), or endowment (waqf) establishments, objectives behind the encouragement of praying at the mosque, and other examples alike. ${ }^{20}$

\section{The Shari'ah's Objectives Pertaining to Transactions (Maqāṣid al- Mu'āmalāt)}

Generally, the objectives of financial transactions (mu' ämalät) would fall under specific objectives category, for the fact that these objectives only deal with certain objectives of a specific branch of knowledge of the Shari'ah. Ibn 'Āshūr identified five objectives for financial transactions, namely: circulation of wealth ( $r a w \bar{a} j$

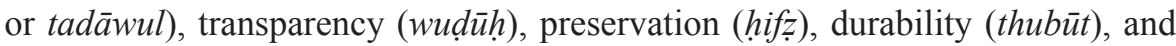
equity ('adl). ${ }^{21}$ 'Abdullāh bin Bayyah, a contemporary scholar of fiqh, considers servitude to Allah ('ibādāh), building civilisation ('imārah), vicegerency (istikhläf), lawful gain or ownership (kasb), and similarly consumption and rightful use of the property (istihlāk) among the many objectives of financial transactions which the Shari' ah upholds ${ }^{22}$ Considering these from the broad range of the five essential objectives identified by al-Ghazālī, these serve the purpose of hifz al-māl (preservation of wealth) altogether. In the following section, we will attempt to identify the objectives which ijärah contract upholds.

\section{The Objectives of the Ijārah Contracts}

As already mentioned, specific contracts and rulings could also have separate objectives, but these should not go against the general objectives of the Shari'ah. 
Likewise, in the ijarrah contract the usufruct and the time period of the contract need to be specified and accurately defined. ${ }^{23}$ This implies that the primary objective of the ijärah contract is access to the usufruct (manfa'ah) of an asset which the lessee needs but does not own. He enjoys the use of the asset for a specified time for a rental. Ijärah also fulfills the objective of circulation of wealth in the market economy as prescribed in the Qur'ān (al-Hashr, 59:7). This is of special relevance to the ijarrah contract where the purpose of the usufruct is to generate wealth. For instance, in ijärah of land which is used to produce crops or food items with the active engagement of farmers, agricultural workers and service contractors. Ijärah as such provides work or business for the lessee; or in the case of ijärah of a lake or a pond which is used for farming fish, ${ }^{24}$ which may then be sold in the market or exported and can thus generate employment opportunities along the line. All of these underline the purpose of wealth generation. Ijārah muntahiyah bi al-tamlīk - which is a modern variant of ijärah, entitles the lessee to own the asset at the end of the lease contract, and serves the purpose of eventual transfer of ownership to the lessee. This is in line with the Qur' annic guideline "so that wealth does not remain concentrated among the rich" (Q 59:7) - the transfer of ownership and the objective of circulation of wealth $(r a w \overline{a j})$ are explicitly realised in this form of ijārah. These are the general objectives of ijārah itself and many of its applications in Islamic finance. These objectives, in effect, fulfill another objective; which is to prevent an asset from being kept idle, remain unutilised or even hoarded (Q 3:180; 9:34-35), a vital means to the growth of market economy. The primary objective of ijārah is to facilitate employment and proper utilisation of services and generally nurture growth of human capital and its flow into the market.

In the Qur'ānic narrative of Prophet Shu 'aib and his two daughters (Q 28: 2627), wherein the Prophet was advised by one of his daughters to hire young Mūsā for wages, the verse implies that an objective of ijärah is to create employment opportunities, where the capability, talent and trustworthiness of employees are ascertained and utilised for production purposes. A perfect relationship between the leader and the follower is also emphasised here. Creating employment opens up the opportunity for development (tanmiyyah), a general objective of Islamic finance - and that the economic and human development is accomplished here.

The essential conditions of the ija rah contract include that the subject should exist at the time of contract, and be for a useful purpose. Since the prime objective is usufruct, things with no usufruct at all cannot be leased. This would include mainly perishable items and foodstuffs. It is also important that both parties in ijarrah should consent to the contract. ${ }^{25}$ This complements the objective of avoiding unjust appropriation and usurpation of another's wealth (akl al-māl bilbațil) (Q 4:29). Similarly, the objective of stability and constancy in wealth is 
also fulfilled with the acknowledgement of ownership and the lessee's legal right to use the property.

Another condition of a valid ijärah is that the usufruct of the asset be defined and specified and that the rental and the period of the lease also be clearly determined. These specifications are meant to fulfill the objective of clarity by avoiding uncertainty and ignorance (gharar and jahälah) in the contract, and thus, prevent possible conflict among the two parties, and a fundamental element in terms of managing risks.

The ijärah based Islamic bond (sukūk), a popular product in the șukūk industry, offers interesting potential for securitisation and development of secondary market for ijārah assets and financiers. Theoretically, these types of șukukk are asset-backed; hence they should be safer, less prone to default, with minimum risk, and an attractive tool for monetisation of untapped assets. However, there are some divergences in practice, due mainly to the fact that most of the ijärah based $s u k \bar{u} k$ are asset-based in which the underlying assets may only be theoretically available, thus failing to fulfill the requirements of asset-backed șukūk.

The prime purpose of such șukuk is to generate liquidity. The real ijārah based suku $k$ are asset-backed in nature, are therefore well accepted due to the fact that they are potential instruments to avoid debt-based securitisation. Debts are detrimental to the economy. Debts, with the interest or profit to be paid over the capital borrowed, cause inflation. In the event of voluminous debts it may be unable to carry government's expenditure capacity for national development; similarly there will be a sharp decrease in investment, as the wealth created is spent out to pay debts. Unemployment, higher cost of living, and instability in the economy are among the other devastating harms that debt may cause. ${ }^{26}$ The asset backed șukūk al-ijärah have the potential to mitigate risks and further maintaining an economy devoid of debt based instruments, and promote a more equitable distribution of wealth in the society.

\section{ljārah and Risk Management}

From the foregoing discussion, we have found that the underlying objectives of the ijärah contract are mainly to ensure transactions are devoid of deception (gharar), usury (ribā), and ignorance (jahālah). Being asset-backed in nature, the ijärah contract is more prone to guarantee default-free transactions, thus mitigating the risks that the bank would have shouldered. Since the agreements should be on mutual consent it leaves behind no scope of doubt among the contracting parties, as such mitigates the risks of information asymmetry as well.

Our central argument in this paper is that if the Islamic banks sincerely ensure that the contracts - ijärah is a case study here - fulfill their inherent objectives, 
it would be easier to manage the diversified risks. It is also important that the banks maintain a synergy between the theories and practical applications so as to eliminate or at least minimise the Shari'ah risks. Therefore, compliance to the objectives of the Islamic financial contracts is an essential tool to mitigate risks and securing a sound Islamic banking system free from risks.

\section{Risk Management in Islamic Banking and Finance}

Risk management is a method by which a financial institution identifies, quantifies and takes appropriate measure either to mitigate or to contain risks. It is imperative since the Shari'ah upholds the principle of blocking the means to evil and harm. In turn, the approach of risk management needs to comply with measures and guidelines envisaged by the Shari'ah encompassing among others, the resistance towards any form of usury and uncertainty. As it signifies the fact that entitlement of income is liable to loss, risk management is closely related to risk sharing. In a trust contract for instance, where financing involves money capital, risk sharing between lender and financier is compulsory whereby the financier does not have legitimate claim for interest money on the capital. ${ }^{27}$

There are some risks which are faced by both Islamic and conventional banks. These shared risks among the banks range from credit risk, liquidity risk, operational risk, FOREX risk, and rate-of-return risk. Besides, there are some other risks which are faced in a higher degree by Islamic banks due to its unique underlying principles and philosophy. Among others, ownership risk is essential in Islamic banks as they involve in real market transactions. In murābahah or ijārah for instance, even though the commodity is immediately sold to clients at the time of purchase, the risks for the first-purchaser (banks) prevail at the post-sale period as clients may somehow sue the banks if the delivered goods do not meet their preferred specifications. Moreover, some have argued that this kind of risk is significantly greater in ijärah contract due to the longer period of such agreement. However, price risk is drastically reduced through the binding promise which is agreed upon in murābahah and financial lease even though it prevails in other forms of financing. Opportunity cost of liquidity risk is higher for Islamic banks as they cannot opt for treasury bills or other interest-bearing instruments and the only alternative is to have murābahah overnight deposits with other Islamic banks. Similar situation applies to moral hazard risk whereby it multiplies in sharing-based finance offered by Islamic banks rather than lending-based conventional finance. ${ }^{28}$ Furthermore, Shari'ah-compliance risk arises from the failure to comply with the Shari'ah rules and principles and to pay due observance on this very aspect is the salient feature of an Islamic bank. 
In managing and mitigating such risks, Islamic banks as well as Muslim investors are more restricted in the use of credit enhancement or risk mitigation techniques as Islamic finance institutions are bound by the principle which closely relates the pursuit of earning profit from an investment in an asset with the bearing of the risks inherent in the asset. This signifies the realism of Shari'ah as it grants the entitlement for a person to earn a return either by expending human hours or by owning an asset that actually and factually produces a return. In turn, any measure to escape from risks will eventually result in the tainting of the ensuing profit by rib $\bar{a}$. Therefore it is essential for Islamic banks to diligently choose techniques that curtail risks which are in tandem with Islamic principles and its objectives. Therefore, theoretically speaking, Islamic bankers need to show their preference for murābahah and ijärah for its minimal risk exposure and their apparent feature in assuring that investors are earning profits by virtue of ownership of assets that grow.

\section{Challenges to Implementing ljārah-based Instruments in Malaysia}

Scholars and experts in Islamic finance seem to unanimously agree on the great potential of ijärah as a viable alternative to interest-based financing. In Malaysia, ijārah has been developed into a new model of financing namely ijārah thumma al-bai ' (a contract of leasing ending with a sale), widely known as AITAB and ijärah muntahiyah bi al-tamlīk (a contract of leasing ending with ownership). The difference between the two is that in the case of the former, the legal title of an asset is transferred to the lessee at the end of the contract through a sale agreement, whereas for the latter, the transfer is effected through gift, token price, or a gradual transfer throughout the lease contract. ${ }^{29}$ While the former is widely utilised in vehicles financing, the latter is adopted by some banks for corporate financing. ${ }^{30}$ Islamic hire purchase contracts in Malaysia fall under the purview of a number of government organs such as the Ministry of Domestic Trade and Consumerism which exclusively owns jurisdiction over higher-purchase ventures, and Ministry of Transportation which handles the approval of vehicle's licence and road tax. Furthermore ijärah has also been adopted in developing an assetbased security product namely șukük al-ijärah, which is the most dominant and widely used for both domestic and international issuance.

\section{The AITAB Enigma}

Even though the above-mentioned theoretical discourse on ijärah suggests fuller compliance with the Shari'ah's objectives pertaining to transactions as a feasible measure for risk mitigation, an inductive analysis of actual practices of AITAB in Malaysian Islamic banks show otherwise. Challenges faced in 
the implementation of AITAB could be categorised into two aspects namely governance and jurisprudential issues. Both are in fact systemic in nature which may inflict effects between each other.

Governance issues or the lack thereof, are indeed the crux of the problem for AITAB instrument. Despite having been one of the most popular Islamic financial instruments, AITAB suffers from a lack of Shari'ah legal framework to govern its practices as it falls under the rubric of conventional Hire Purchase Act 1967. Therefore, any disputes regarding such transaction will be referred to the conventional regulation. Furthermore, with regard to determination of fixed rate, standard documentation, and formation of agreement, AITAB transaction is a replication of the Hire Purchase Act 1967. In terms of court's jurisdiction, Islamic banking transactions also fall under the civil court's jurisdiction and the court handles commercial case by referring to the existing law. Although the Hire Purchase Act contains some advantageous features, ${ }^{31}$ it somehow violates the original spirit and objectives of ijärah and the basic principles and requirements of Islamic transactions such as unclear documentations in respect of ijārah and sale contract, limited application to just a certain type of goods, as well as the involvement of interest calculation for its term charges. ${ }^{32}$ Some Islamic banking practitioners have in fact put their utmost effort to introduce an alternative legal framework so as to govern the practice of AITAB by proposing the Mu'amalah Higher Purchase Bill (2002). The Bill provides a Shari'ah compliance framework for hire purchase transaction, as well as offering a wider scope of application covering houses of not more than RM250, 000 and machinery equipments. The Bill has gone through its proper passage from the Attorney General's Office and the Prime Minister's Office, but it is yet to be implemented..$^{33}$

Besides the above-mentioned issues, there are several other drawbacks with regard to the practice of AITAB which range from customers' attitude, lack of experienced bank officers to handle such transactions, poor awareness and cooperation among dealers, complicated documentations, and competition with the conventional higher purchase instrument in the market. ${ }^{34}$

The jurisprudential or legal issues on the other hand encompass issues of ownership, maintenance, liability, penalty, and legal treatment. ${ }^{35}$ Regarding the issue of ownership, banks as owner of assets in AITAB instruments are supposed to take on risks, liabilities and responsibilities on those assets. However, in practice, banks attempt to avoid all kind of responsibilities despite claiming the ownership of the assets. For instance, according to the principle of ijärah, the lessor who is at the same time the owner of the leased asset, needs to bear any cost pertaining to the asset. This could possibly include the cost of insurance for motor vehicles. However, the current practice in Malaysia shows that the lessee is the one who is responsible for the insurance cost of vehicle in the AITAB 
contract. This measure is legally backed by Section 26(1) Hire Purchase Act 1967 which clearly states that owner of the vehicle (bank) is liable to bear the insurance cost for the first year under lessee's name and Section 26(2) of the same enactment that elucidates the lessee's responsibility to bear the insurance cost for the next two years and the following years. ${ }^{36}$ Besides this, even though the leased asset under AITAB is registered under the name of the bank, surprisingly it is not recorded as fixed assets of the bank. This evidently shows that banks attempt to minimise their commitment and liability to the risks and ownerships of the leased assets. Furthermore the hire purchase instrument offers no option of defect (khiyār al- 'aib) ${ }^{37}$ to the lessee to either reject or cancel such transaction, which will cause injustice to the lessee. In summing up, AITAB instrument is seen to adopt a risk transfer approach that transmits all possible risks to the lessee rather than opting for a risk sharing measure which is an inherent attribute in the original ijārah contract. ${ }^{38}$

There are also some alarming issues with regard to the calculation of profit margin or term charges in AITAB which are actually measured by referring to interest rates which are independent from the real value of the asset's usufruct. Abdul Halim and Sharman explicate on the two assessments method of the hire purchase financing instruments adopted by Islamic banks in Malaysia, namely Constant Rate of Return (CRR) and Rule 78. While the former was originally used by conventional banks in determining the value of lease contract, the latter was introduced in 1995 in conjunction with AITAB's initiation by Bank Islam. CRR formulates reductions in the lessor's principal due to amortisation of payments of such principal by the lessee. This is in fact an indirect gradual purchase of the assets by the lessee whereby the lessor ownership will decrease with time until it is wholly owned by the lessee at the end of the contract. CRR has somewhat adopted the principle of mushärakah mutanāqișah (MM) which signifies a partnership with the decline of ownership on the lessor's part. However, unlike MM, CRR does not take into account the sharing ratio for determining the parties' profits. Rule 78 on the other hand employs the concept of simple interest - principal plus the profit - where its profit is based on interest rate. ${ }^{39}$ Therefore, both CRR and Rule 78 are bounded by the concept of time value of money that has no significant variation from conventional method. ${ }^{40}$ Moreover, in the event of default, a lessee is expected to pay the amount of rent up to the period of repossession together with the cost of repossession. This measure is in fact a carbon copy of conventional repossession procedure whereby the calculation method for the contract settlement is currently referred to in such procedures. ${ }^{41}$ 


\section{Shari'ah Issues of Ijārah-based Islamic Bonds (Șukūk al-ljārah)}

Sukūk al-ijärah are 'securities of equal denomination of each issue, representing physical durable assets that are tied to ijärah contracts as defined by Shari'ah' ${ }^{42}$ It can be divided into three categories; sukuk for the ownership of leased tangible assets, sukūk for the ownership of usufruct, and șukuk for the ownership of services. It is worth noting here that the unique attribute of sukük al-ijārah is that the underlying assets are not present at the time when the contract is concluded as they are yet to be produced or provided. Despite being an asset-based instrument șukūk al-ijārah has however been subjected to criticisms in term of its process of development and implementation. ${ }^{43}$

One of the issues that is highlighted with regard to sukuk al-ijärah is the commitment imposed on the șukük holders to lease the asset which has been sold to them, to the obligor. Even though there are some classical scholars from the Hanafites, Shafi'ites, and Hanbalites schools who deem that such an arrangement resembles the bay ' $a l$ - 'inah ${ }^{44}$ in usufruct, there are other scholars who permit such practice on the ground that it does not conflict with the nature of sale contract.

Moreover, there is also concern pertaining to the promise made by the original owner to repurchase the asset after the lease period especially at their face value price. Even though some fiqh councils in Malaysia have declared the permissibility of such practices the opposing position is worth taking into account. Some scholars have argued that a binding promise from sukuk issuer to repurchase the asset of șukuk al-ijärah is tantamount to capital guarantee which is absolutely prohibited. It is in fact an exchange of spot cash for a greater amount of delayed cash due to the fact that the asset is not really transferred to the sukuk holder in the real sense. Furthermore, this arrangement contravenes the very objective of Islamic transactions that is the distribution of profits emanate from real commercial ventures on a just basis $(r a w \bar{a} j)$. On top of that, the structure of the sukük al-ijärah with such kind of binding promise totally resembles an interest-bearing bond.$^{45}$ Therefore, this controversial feature might finally induce Shari'ah risk on șukük al-ijärah in the future if it is perceived to be contradicting Shari'ah's guidelines and objectives.

\section{Conclusions and Recommendations}

Due to its basic advantages and its compliance to the higher objectives of Shari'ah particularly in economic transactions, ijārah has become a feasible alternative to the controversial Islamic financial instruments such as bay ' al- 'inah and bay 'aldayn. This has generated substantial interest among governments and financial companies in ijärah-based financing and securitisation due to its potential in financing infrastructure developments and services. It is interesting to note that 
in his October 2014 National Budget speech, Malaysia's Prime Minister Najib Razak has announced that Malaysia is extending tax break on sukuk structures that are acceptable to Middle Eastern investors which are the ijärah and wakālah bonds up until the year 2018. He also indicated that the same incentive is no longer given for tawarruq. Apparently, such measure aims to attract more șukük investor globally due to the wide acceptance of ijärah and wakälah among scholars as well as to do away with tawarruq or commodity muräbahah due to its contentious status. ${ }^{46}$ It is indeed a commendable initiative by the Malaysian government in the pursuit of promoting maqāssid-compliance financial instruments which are directed to the real economy. Nevertheless, those abovementioned Shari'ah issues pertaining to ijärah-based instruments in its actual implementation do need attention from policy makers and industry practitioners in order to find feasible solutions for the governance and jurisprudential predicaments in both AITAB and sukūk al-ijärah. In this respect, several recommendations for the improvement of ijārah-based instruments to ensure its compliance with the Shari'ah's objectives regarding financial transactions is proposed here as follows:

1. The government of Malaysia should take proactive measures in order to resolve the legal hurdles over the implementation of AITAB. This can be done either by enacting the Mu'amalah Hire Purchase Bill as its legal framework or by adding some amendment to the Hire Purchase Act 1967. Enacting Mu'amalah Hire Purchase Bills also means that Shari'ah courts need to be given wider jurisdictions so as to make judgement in commercial cases. Nonetheless, the feasible solution at the moment is to infuse some Islamic compliance elements within the existing hire purchase enactments.

2. The calculation method for profit margins or term charges in AITAB need to incorporate a profit-sharing ratio in order to determine the distribution of profits (or losses) between the contracting parties.

3. Banks should adopt a risk-sharing method in providing the AITAB financial services to their customers. Therefore they need to bear some reasonable maintenance costs of the leased-assets. Alternatively, banks could also employ the principle of mushärakah mutanāqișah if they are reluctant to bear the ownership liability of the leased-assets.

4. Lessee should be given the option of defect (khiyār al- 'aib) in cases where the asset's specification does not meet the contract's agreement.

5. In sukūk al-ijärah, the issuer should redeem the ownership of the usufruct after allotment and subscription payment, at the marker price, or an agreeable price between the transacting parties, on the condition that the redemption price is not deferred.

6. Sukukk issuer or manager should not guarantee the principal or income of 
the bond in the event of total or partial damage due to the fact that the loss needs to be borne by the șukūk-holder.

\section{Notes}

* Ahmad Badri bin Abdullah is Research Fellow at IAIS Malaysia, with a focus on maqasid al-shari'ah (the higher objective of Shari ah), usul al-figh, and contemporary Islamic jurisprudence discourse. He is pursuing his $\mathrm{PhD}$ in the study of maslahah. He can be contacted at badri@iais.org.my.

* Tawfique Al-Mubarak is a Research Fellow at International Institute of Advanced Islamic Studies, Malaysia. The author is thankful to Dr Tazul Islam for his insights on the concept behind this paper. He can be contacted at tawfique@iais. org.my.

1. E. W. Lane, An Arabic-English Lexicon, Vol. 1 (Beirut: Librarie Du Liban, 1968), 23-24; Abdullah Alwi H. Hassan, Sales and Contracts in Early Islamic Commercial Law (KL: The Other Press, 2007), 226; Muhammad Ayub, Understanding Islamic Finance (UK: Wiley \& Sons 2007), 279.

2. 'Alā al-Dīn Al-Kāsān̄i, Badā'i ' al-Șanā' 'i' fì Tartīb al-Sharā'i', Vol. 4 (n.p.: Dār al-Kutub al-'Ilmiyyah, 1986), 174. The term ujär has been used in the Qur' ān for the wage in hiring a wet nurse (65:6) and the dowry in exchange for the marriage contract $(4: 25)$ as well, wherein it denotes the counter value for a usufruct.

3. Al-Mausū' 'ah al-Fiqhiyyah al-Kuwaitiyyah, 252-253; Abū 'Umar Y. 'Abdillāh al-Qurțubī, Al-Kāfì fì Fiqhi Ahlu al-Madīnah, Vol.2 (Riyāḍ: Maktabah al-Riyāạ al-Hadìthah, 1980), 744, 753-754.

4. 'Uthmān Shubayr, Al-Mu 'àmalāt al-Māliyyah al-Mu 'ạșirah fí al-Fiqhil Islāmī, $4^{\text {th }}$ ed. (Amman: Dār al-Nafā' is, 2001), 326.

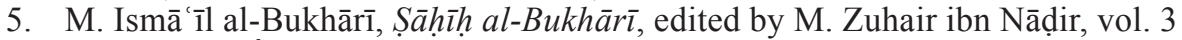
(Beirut: Dār Ùūq al-Najāt, 1422 H.), 89, hadīth no.: 2264.

6. Abū 'Abdullah Ibn Mājah al-Qazwīnī, Sunan Ibn Mājah, edited by Fu'ād 'Abdul Bāqī, vol. 2 (n.p.: Dār Iḥyā' al-Kutub al-'Arabiyyah, n.d.) 817; hadīth no.: 2443. The ḥadīth has been authenticated by Nāșir al-Dīn Albānī, Irwā' alGhalīl fì Takhrīj Ahāàith Manìr al-Sabìl, vol. 5 (Beirut: al-Maktab al-Islāmī, 1985) 320.

7. Al-Mausū 'ah al-Fiqhiyyah al-Kuwaitiyyah, Vol. 1, 254; Al-Kāsānī, vol. 4, 174; Muhyū al-Dīn Sharaf al-Nawawī, Rawdatul-Ṭālibīn wa 'Umdah al-Muftīn, edited by Zuhair al-Shīwīsh, vol. 5 (Beirut: Al-Maktab al-Islāmī, 1991), 173

8. Cf., Al-Kāsānī, Badā' 'i', vol. 4, 176

9. Mufti M. Taqi Usmani, An Introduction to Islamic Finance (e-book), accessed on $22^{\text {nd }}$ March, 2013, http://www.muftitaqiusmani.com/index. php?option $=$ com_content $\&$ view $=$ article $\&$ id $=6$ :an-introduction-to-islamic-

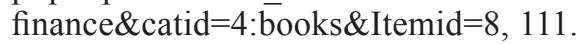

10. Cf., al-Kāsān̄̄, Badā'i ', vol. 4, 175

11. Cf., al-Fatāwā al-Hindiyyah, vol. 4, 411

12. Cf., Abdullah Alwi H. Hassan, Sales and Contracts, 229

13. Cf., Mufti M. Taqi Usmani, An Introduction, 112 
14. Jasser Auda, Maqāșid al-Sharī'ah as Philosophy of Islamic Law: A Systems Approach (London and Washington: IIIT, 2008), 2-3.

15. Ibid.

16. Mohammad Hashim Kamali, Maqāșid al-Sharī'ah, Ijtihād and Civilisational Renewal (London and Washington: IIIT, and KL: International Institute of Advanced Islamic Studies (IAIS) Malaysia, 2012), 17-18. In fact, the mașālīh mulgha are unacceptable, as the term itself suggests.

17. Al-Ghazālī, Shifā' al-Ghalīl in Imran Ahsan Khan Nyazee, Outlines of Islamic Jurisprudence (e-book: Advanced Legal Studies Institute, n.d.), 165.

18. Ibrāhīm ibn Mūsā (Abū Isḥāq) al-Shāțibī, Al-Muwāfaqāt fì Ușūl al-Sharī ah, A. 'U. Mashhūr Hassan, ed. (7 volumes) (n.p.: Dār Ibn 'AffÉn, 1997), V.2, 17 22; and Auda, Maqāșid al-Sharī'ah, 3-4.

19. Aḥmad al-Raysūn̄̄, Madkhal ilā Maqāṣid al-Sharī ah (Cairo: Dār al-Salām, and Rabat: Dār al-Amān, 2010), 11-13; and Auda, Maqāṣid al-Sharī'ah, 4-5.

20. Auda, Maqāșid al-Sharī'a: A Beginner's Guide, 6-7.

21. M. Țāhir Ibn 'Āshūr, Ibn Ashur's Treatise on the Higher Objectives \& Intents of Islamic Law, 282.

22. See 'Abdullāh bin-Bayyah, Maqāsșid al-Mu'āmalāt wa-Marāșid al-Wāqi 'āt (London: Al-Furqan Islamic Heritage Foundation, 2010), 69-77.

23. Cf. 'Uthmān Shubayr, Al-Mu'āmalāt al-Māliyyah, 326.

24. Such ijärah of lakes or ponds are not permissible in the Hanafi School, as the leased item (water) is a fungible item. However, other Schools have permitted it. See al-Kāsān̄̄, vol. 4, 175; and al-Mausū' 'ah al-Fiqhiyyah al-Kuwaitiyyah, Vol. 1, 277. In fact, Ibn Qaiyyim considers all such ijärah permissible because here one can benefit from the asset which is reproduced after consumption while the corpus remains in its original form. Ibn Qaiyyim based his argument on the Qur'annic verse of hiring a wet nurse (65: 6), which itself is a corpus ( 'ayn) allotted for ijārah.

25. Cf., al-Fatāwā al-Hindiyyah, vol. 4, 411.

26. For a detailed discussion on the effects of debt, see Abdul Karim Abdullah, "Debt and Economic Activity," Islam and Civilisational Renewal (ICR) 4, no 3 (2013): 407-22.

27. M. Kabber Hassan \& Rasem N. Kayed, "The Global Finance Crisis, Risk Management and Social Justice in Islamic Finance" ISRA International Journal of Islamic Finance, v.1, no.1 (2009), 44-46.

28. Monzer Kahf, "Maqāșid al-Sharī'ah in The Prohibition of Ribā and Their Implication For Modern Islamic Finance", Paper presented at IIUM International Conference on Maqasid al-Shari'ah, IIUM Malaysia, 8-10 August 2006, 19. Available online at, http://www.assaif.org/Modes-of-Financing/Ribà-Interestrate/Maqasid-al-Shari'ah-in-the-Prohibition-of-Riba-and-their-Implicationsfor-Modern-Islamic-Finance> accessed on 15 December 2014.

29. Mohd Herwan \& Mohd Hawari, Understanding Shari'ah and Its Aplication in Islamic Finance, (Kuala Lumpur: IBFIM, 2011), 132-135.

30. N. Irwani Abdullah \&Asyraf Wajdi Dusuki, "A Critical Appraisal of al-Ijārah Thumma al-Bay' (AITAB) Operation: Issues and Prospects", Paper presented at $4^{\text {th }}$ International Islamic Banking and Finance Conference, Monash University, Kuala Lumpur, 13-14 November, 7-8. 
31. It provides protection to hirers and guarantors against unscruplous dealers, clear procedure and formalities of transaction, indicates rights and liabilities of the owner, hirer, and guarantor, as well as remedy and penalty for claimant and offernder. See Ibid, 11.

32. Md. Abdul Jalil, "Islamic Hirer Purchase Law is Getting Special Attention in Malaysia: A Socio-Legal Analysis," Journal of Sociological Research, v.4, no.2 (2013), 29-31.

33. See N. Irwani Abdullah, "Implementation of Muamalah Hire Purchase Bill in Malaysia: Chasing A Mirage?” IIUM Law Journal, v.17, (2009), 99 -123.

34. Nuzul Azma et. al, "Issue and Prospect of Islamic Hire Purchase Financing: Malaysian Evidence," Journal of Management Research, v.6, no.1(2014), 17.

35. Hashim Ahmad Shiyuti et.al (2012), "Critical Evaluation on al-Ijārah Thumma al-Bay',," Paper presented at Asian Finance Association (AsfA) Conference, 2013, 35 .

36. Hire Purchase Act 1967(Act 212) \& Regulation, available online at <www. kpdnkk.gov.my/c/document_library/get_file?uuid...> accessed on 30 November 2014.

37. See Mohammad Hashim Kamali, "A Shari'ah Analysis on Issues in Islamic Leasing” Islamic Econ, v.20, no.1 (2007), 11.

38. See Aisyah Abdul Rahman \& Rahazilah Rahman, "Evaluation on al-Ijārah Thumma al-Bay' (AITAB) Facility: The Case of Affin Islamic Bank Berhad", Paper presented at the $5^{\text {th }}$ Asia-Pacific Bussiness Research Conference, Kuala Lumpur, 17-18 February, 16.

39. Nurfadhlina Abdul Halim \& Saiful Hafizah Jaaman@Sharman, "The Critique of Islamic Hire Purchase Instrument and Its Improvement," Paper presented at the $9^{\text {th }}$ International Conference on Islamic Economics and Finance, Istanbul, 9-10 September 2013, 3-5.

40. B.S Chong \& M.H.Liu, "Islamic Banking: Interest-Free or Interest-Based?" Pasific-Basin Finance Journal, 17(2009), 125-144.

41. See Mahmood Mohamed Sanusi, Islamic Banking and Finance Shari'ah \& Legal: Issues and Challenges, (Selangor: Aslita, 2012), 156.

42. Monzer Kahf, "The Use of Assets Ijārah Bond for Bridging the Budget Gap." Islamic Economic Studies, v.4, no.2(1997), 82.

43. Said Muhammad Bouheraoua et.al, "A Critical Appraisal of Shari'ah Issues Related To Șukūk Al-Ijārah” ISRA International Journal of Islamic Finance, v.4. no.1(2012), 167.

44. It refers to an arrangement that involves sale of an asset to the purchaser on a deferred basis and subsequent purchase of the asset at a cash price lower than the deferred sale price or vice versa. See Bank Negara Malaysia, al-Bay' al'Inah, Exposure Draft, 4.

45. Ibid,174. See also Muhammad Ridhwan Ab.Aziz et.al, "The Structure of Șukūk Ijārah: An Initial Analysis From The Perspective of Maqasid Al-Shari'ah"

46. Elffie Chew and Liau Y-Sing, "Malaysia Tax Incentives Chase Stringent Fund: Islamic Finance", Bloomberg Bussiness Week, accessed online on 17 November 2014 <http://www.businessweek.com/news/2014-10-14/malaysiatax-incentives-chase-stringent-funds-islamic-finance $>$ 